\title{
PERKIRAAN TINGGI STANDAR LANTAI JEMBATAN TERHADAP PENGARUH MUKA AIR BANJIR
}

\author{
Mursid MA ${ }^{1, \square)}$, Deny Yatmadi $^{2}$ \\ 1,2 Jurusan Teknik Sipil, Politeknik Negeri Jakarta, Jalan Prof.Dr.G.A.Siwabessy, Kampus UI, 16425. \\ e-mail : ${ }^{1}$ mursidmufti@gmail.com, ${ }^{2}$ denny_yatmadi@gmail.com
}

\begin{abstract}
One of the bridge crossing of the Ciliwung River at the upstream side entered DKI-Jakarta area is MT. Haryono Bridge, where the bridge has the heavy and jam traffics. Every rainy season, water level of Ciliwung River flood always increase, where the peak point of the flood was occured on February in 2007, the water level exceeded the bridge deck level. Therefore, it would be necessary to determine a height standard of the bridge deck of MT.Haryono bridge against to the water level of Ciliwung River when the peak flood occured, the existing of the elevation at the below of the bridge deck is +18.50 meter and the elevation above the bridge deck is + 19.50 meter. Hydrology analysis using Log Pearson type III performed to determine the data of average daily and yearly rainfall around of catchment area of Ciliwung River with using the water level control point near Kalibata Bridge and the flood hydrograf was calculated using synthetic hydrograph method from Nakayasu. Hydraulic analysis utilized the of HEC-RAS software (4.1) using the maximum value of hydrograph unit and consists of two simulations, where the first is simulation of calibration model of Ciliwung River at the upstream side based on the flood occured on February 04th 2007 (called as $Q_{2007)}$ and the second simulation using some scenarios for some return period of 2, 5, 10, 20,50, 100 years. Every result of both simulations generates the height of bridge deck from the water level of flood according to the exsisting requirements. From these results, it could be determined the elevation of bridge deck for return period of flood for the peak flood 2007 and for 2, 5, 10, 20, 50, 100 yearly, and, such as +19.50, +20.50, +21.00 , +21.10, +21.80, + 22.10 dan 22.00 meter.
\end{abstract}

Keywords: flood analysis, HEC-RAS hydrograph, bridge deck elevation.

\begin{abstract}
ABSTRAK
Sepanjang alur Sungai Ciliwung Hilir yang masuk wilayah DKI-Jakarta banyak terdapat bangunan struktur melintang, salah satunya Jembatan MT. Haryono. Jembatan ini dilintasi oleh jalan Tol dan jalan Alteri yang terletak di ruas Jalan Utama Ibukota yaitu pada jalan MT. Haryono yang ramai dan padat lalulintasnya Setiap musim hujan muka air banjir Sungai Ciliwung selalu naik, puncaknya pada bulan Februari tahun 2007 muka air banjir berada lebih kurang satu setengah meter diatas lantai jembatan, sehingga jembatan tidak dapat berfungsi sebagaimana mestinya, dan menyebabkan lululintas menjadi terganggu menimbulkan macet. Oleh karena itu perlu dilakukan penelitian untuk mendapatkan tinggi standard lantai jembatan MT Haryono terhadap muka air banjir sungai Ciliwung Dalam penelitian ini dilakukan analisa hidrologi dan analisa hidrolika. Analisa hidrologi menggunakan data hujan harian rata-rata DAS Ciliwung dengan titik kontrol Jembatan Kalibata, hidrograf banjir dihitung menggunakan metode hidrograf satuan sintetik Nakayasu. Analisa hidrolika dilakukan menggunakan bantuan softwere HEC-RAS 4.1.0. Dalam analisis hidrolika terdiri dari dua simulasi, pertama simulasi kalibrasi model Sungai Ciliwung Hilir pada kondisi eksisting berdasarkan kejadian banjir pada tanggal 4 Februari 2007 (Q2007) dan kedua simulasi diskenariokan dengan beberapa kala ulang banjir 5, 10, 20,50, 100 tahun. Setiap hasil simulasi dievaluasi untuk mendapatkan tinggi standard lantai jembatan dari muka air banjir yang memenuhi syarat. Dari hasil analisa hidrologi untuk hujan maksimum harian digunakan distribusi Log Perarson III dan dari nilai maksimum hidrogaf satuan maka dilakukan analisis hidrolika dengan softwere HEC-RAS diperoleh masing-masing elevasi muka air banjir dilokasi jembatan.Dari hasil analisis tersebut ditentukan elevasi lantai jembatan yang ideal. Elevasi lantai jembatan standar sesuai kala ulang banjir 2, 5, 10, 20, 50, 100 tahunan, banjir 2007 sebagai berikut +19.50, +20.50, +21.00, +21.10, +21.80, + 22.10 dan 22.00 meter.
\end{abstract}

Kata kunci: analisis debit banjir, hidrograf HEC-RAS, elevasi lantai jembatan 


\section{PENDAHULUAN}

Sungai Ciliwung adalah salah satu dari 14 sungai yang cukup besar melintasi bagian tengah dari DKI-Jakarta, Pada musim hujan sungai ini sering banjir atau disebut oleh umum sebagai banjir kiriman dari wilayah Kota Bogor. Sepanjang alur Sungai Ciliwung Hilir terdapat tujuh buah jembatan besar, diantaranya yaitu Jembatan, Kalibata, MT. Haryono, Casablangka, Bukitduri, Slamet Riyadi dan Jembatan Pintu Air (PA) Manggarai. Sebahagian besar jembatan terrendam, khusus Jembatan MT. Haryono terendam hingga setinggi $1.50 \mathrm{~m}$ diatas elevasi lantai jembatan sewaktu banjir besar pada bulan Februari 2007, sehingga fungsi jembatan sebagai bangunan penghubung jalan raya tidak dapat berfungsi sebagaimana mestinya, Jembatan yang baik adalah jembatan yang memiliki ruang bebas yang cukup antara bawah lantai jembatan dengan elevasi muka air banjir tertinggi 1 meter Oleh karena itu perlu dilakukan evaluasi tinggi lantai Jembatan MT. Haryono terhadap muka air banjir Sungai Ciliwung.

Penelitian ini dimaksudkan untuk melakukan kajian elevasi muka air banjir yang terjadi diatas Jembatan MT.Haryono pada kondisi banjir tahun 2007. Sedang tujuan dari penelitian ini adalah untuk menentukan elevasi lantai jembatan MT.Haryono setiap kala ulang banjir yang memenuhi standar jembatan.

Hasil penelitian ini diharapkan dapat memberikan masukan kepada pengelola jembatan MT.Haryono sebagai pertimbangan untuk menyesuaikan elevasi lantai jembatan untuk menghindari terendamnya jembatan akibat banjir Sungai Ciliwung.

Tambunan (2005) menyebutkan satu hal terpenting yang dilupakan adalah penyebab utama banjir yang sering diduga disebabkan oleh perubahan peruntukan lahan di kawasan Puncak. Padahal penyebab utama adalah tingginya koefisien limpasan di daerah tengah antara Katulampa-Ratujaya.

Saat ini, koefisien limpasan di Katulampa tercatat sebesar 38 persen, di Ratujaya 48 persen, dan di Manggarai 54 persen. Semakin kecil koefisien aliran Sungai Ciliwung semakin kecil pula debit banjir yang terjadi sehingga mempengaruhi elevasi lantai jembatan. Dinas Pekerjaan Umum DKI Jakarta (2009) Peningkatan Kapasitas Pintu Air (PA) Manggarai. Perkiraan debit banjir 100 tahunan Sungai Ciliwung masuk ke Pintu Air Manggarai sebesar 580 $\mathrm{m}^{3} /$ det, sedang kemampuan pintu-pintu air Manggarai mengalirkan debit banjir ke Banjir Kanal Barat hanya sebesar $360 \mathrm{~m}^{3} /$ det.

Sebaiknya Pintu Air Manggarai perlu ditingkatkan kapasitasnya menjadi 580 $\mathrm{m}^{3} /$ det. Dengan ditambahnya pintu air Manggarai dapat mengurangi elevasi muka air di PA Manggarai dan di Sungai Ciliwung yang mempengaruhi elevasi bangunan struktur yang ada di sepanjang alur sungai Ciliwung Hilir.

Waluyadi (2007) menyebutkan perencanaan pengelolaan banjir dengan menggunakan saluran pengelak banjir/sudetan dari Sungai Ciliwung ke Banjir Kanal Timur. Pintu air yang digunakan adalah jenis pintu air sorong tegak, dengan lebar pintu 3,5 meter tinggi 7 meter, memberikan penurunan tinggi elevasi muka air banjir pada kondisi banjir kala ulang 25 tahunan sebesar $164 \mathrm{~cm}$ sampai 192 cm, Dengan adanya sudetan aliran ini mengurangi elevasi Muka Air Banjir (MAB) dibeberapa titik pengamatan yang dapat memberikan pengaruh terhadap elevasi lantai jembatan dan elevasi tanggul yang ada di hilir intek sudetan.

Masing-masing penakar mempunyai daerah pengaruh yang dibentuk dengan 
menggambarkan garis-garis sumbu tegak lurus terhadap garis penghubung di antara dua buah pos penakar. Curah hujan rata - rata daerah metode polygon Thiessen dapat dihitung dengan persamaan sebagai berikut (Soemarto, 1999):

$d=\frac{A_{1} d_{1}+A_{2} d_{2}+\ldots+A_{n} d_{n}}{A_{1}+A_{2}+\ldots+A_{n}}=\sum_{i=l}^{n} \frac{A_{i} d_{i}}{A_{i}}=\sum_{i=l}^{n} \frac{A_{i} d_{i}}{A}$

Curah hujan rencana adalah curah hujan terbesar tahunan yang terjadi pada periode ulang tertentu. Pada daerah studi, pemilihan metode perhitungan hujan rencana ditetapkan berdasarkan parameter dasar statistiknya.

Pemilihan Metode Perhitungan Hujan Rancangan Persyaratan statistik dari beberapa distribusi, sebagai berikut :

1. Distribusi Normal

2. Distribusi Gumbel

3. Distribusi Log Pearson Tipe III

Rumus dari hidrograf satuan sintetik (HSS) dari Nakayasu diperlihatkan dalam Gambar 1 dan persamaan berikut:

$Q_{p}=\frac{A \cdot R_{0}}{3,6 \cdot\left(0,3 \cdot T_{p}+T_{0,3}\right)}$

Perhitungan hidrolika amatlah rumit, mengingat bentuk penampang sungai tidak seragam dengan jumlah yang banyak. Untuk melakukan analisa cukup sulit apabila tidak dibantu oleh suatu perangkat lunak HEC-RAS 4.1.

\section{METODE PENELITIAN}

Metode penelitian dilakukan mengikuti tahapan sebagaimana diagram alir diperlihatkan Gambar 2.

Pada tahap persiapan dan tinjauan pustaka berisikan tentang diskripsi Jembatan MT.Haryono, tinjauan pustaka berisikan tentang review yang berhubungan dengan persoalan atau masalah yang berkaitan dengan elevasi muka air banjir DAS Ciliwung.

Dasar teori pendukung dalam melakukan analisa hidrologi dan hidrolika serta dasar teori program atau softwere HEC-RAS yang dipakai untuk menganalisis hidrolika S. Ciliwung.

Analisis Hidrologi membahas tentang pengolahan curah hujan, menghitung curah hujan wilayah dengan metoda poligon Thiessen, menentukan curah hujan rancangan metode didtribusi Log Person Type III, menghitung curah hujan jam-jaman dengan metode Mononobe menghitung hidrograf banjir dengan metode Nakayasu (HSS). Tabel 1 adalah Hasil Perhitungan Curah Hujan dengan Bobot Poligon Thiessen.

Analisis hidrolika membahas tentang perencanaan skema simulasi sungai Ciliwung yang dipakai sebagai lokasi analis hidrolika, mengimput data geometri sungai dan input flow data (aliran). Melakukan koalibrasi simulasi model banjir kejadian Februari 2007 dan melakukan simulasi model dengan debit rencana sesuai kala ulang banjir. Merekap hasil simulasi model dari kedua simulasi Melakukan pembahasan tentang hasil simulasi yang berhubungan dengan muka air banjir.

\section{HASIL dan PEMBAHASAN}

Hasil penelitian yang ditampilkan dalam adalah hasil dari analisis data sekunder hidrologi DAS Ciliwung dan data sekunder hidrolika geometri S. Ciliwung yang dilakukan mengikuti diagram alir penelitian.

Deskripsi jembatan sebagai berikut:

a. Lokasi jembatan terletak pada jalan MT.Haryono melintasi sungai 
Ciliwung wilayah Jakarta Selatan dan Jakarta Timur (Gambar 3).

b. Jembatan terbuat dari kontruksi beton bertulang

c. Panjang jembatan 30 meter dan lebar jembatan 32 meter.

d. Elevasi lantai atas jembatan +19.50 $\mathrm{m}$ dan elevasi bawah lantai $18.50 \mathrm{~m}$

e. Elevasi MAB tertinggi $+21.00 \mathrm{~m}$ terjadi pada bulan Februari 2007.

Curah hujan rata-rata wilayah DAS Ciliwung untuk kondisi eksisting Februari 2007 dan kondisi sesuai data curah hujan eksisting terlihat pada Tabel 2.

Hasil hitungan analisis frekwensi diperoleh metoda terbaik adalah Metoda Log Pearson Tipe III seperti terlihat dalam Tabel 3.

Hasil analisis distribusi hujan eksisting pada bulan Februari tahun 2007 dan hujan sesuai kala ulang hujan diperoleh hujan jam-jaman diperlihatkan oleh Tabel 4 dan 5.

Hasil analisis pada hidrograf banjir diperlihatkan Gambar 4 dan Tabel 6 adalah grafik gabungan hidrograf banjir eksisting bulan Februari tahun 2007 dan hidrograf banjir kala ulang $\left(\mathrm{T}_{\mathrm{r}}\right)$.

Hasil analisis hidrolika pada kondisi eksisting bulan Februari 2007 diperoleh profil dan elevasi Muka Air Banjir (MAB) seperti terlihat pada Gambar 5 dan 6 dan Tabel 7.

Hasil simulasi hidrolika kondisi kala ulang banjir yang diskenariokan $\left(\mathrm{T}_{\mathrm{r}}=\right.$ 2, 5, 10, 20, 50 dan 100 tahun) diperoleh elevasi muka air banjir seperti terdapat dalam Tabel 8; Gambar 4 sampai 6 memperlihatkan elevasi MAB pada jembatan MT.Haryono sesuai dengan kala ulang banjir.
Setelah dilakukan simulasi kalibrasi model kondisi banjir eksisting Februari 2007 dengan bantuan HEC-RAS dibandingkan dengan hasil pengamatan MAB eksisting yang terjadi pada Februari 2007 disetiap titik pengamatan diperoleh perbedaan kesalahan rata-rata elevasi MAB dibawah 5\%. simulasi kalibrasi ini dapat diterima. Hasil kalibrasi dapat dilihat pada Tabel 9.

\section{KESIMPULAN}

Hasil analisis hidrologi dan hidrolika S. Ciliwung Hilir untuk elevasi lantai jembatan MT.Haryono terhadap muka air banjir S. Ciliwung yang sudah dilakukan diperoleh bahwa elevasi lantai jembatan MT.Haryono rata-rata berada di elevasi muka air banjir. Oleh karenanya elevasi lantai jembatan sebaiknya dinaikan sampai elevasi tertentu sesuai dengan kala ulang banjir yang terjadi, sehingga jembatan akan berfungsi sebagaimana mestinya meski S. Ciliwung dalam keadaan banjir, diperlihatkan dalam Tabel 10 dan Gambar 7 pada kondisi normal.

\section{UCAPAN TERIMAKASIH}

Tim Peneliti mengucapkan terima kasih atas pendanaan penelitian kepada Pusat Penelitian dan Pengadian Masyarakat (P3M), Politeknik Negeri Jakarta.

\section{DAFTAR PUSTAKA}

[1] Anonim, 2008, Perencanaan dan Detail Desain Penataan Kali Ciliwung dari Pintu Air Manggarai ke Hulu, PT. Daya Cipta Dianrancana, Jakarta.

[2] Anonim, 2017. Rencana Detail Penanganan Banjir Jabodetabekjur (2), Balai Pengelolaan Daerah Aliran Sungai Ciliwung Cisadane, Jakarta. 
[3] Bambang Triatmodjo, 2010, Hidrologi Terapan, Beta Offset, Yogyakarta.

[4] Heriantono Waluyadi, 2007, Kajian Penanganan Banjir Kali Ciliwung DKI Jakarta Ditinjau Dari Aspek Hidro-Ekonomi Tesis, Program MPBA, Sekolah Pascasarjana, UGM, Yogyakarta.

[5] Istiarto, 2010, Simulasi Aliran 1 Dimensi Dengan Bantuan Paket Program Hidrodinamika HEC RAS, Modul Pelatihan, Program MPBA, Sekolah Pascasarjana,UGM, Yogyakarta.
[6] Mangapul Parlindungan Tambunan, 2005, Pola wilayah genangan air di daerah aliran Ciliwung (studi kasus Wilayah Jakarta periode La-Lina) Desertasi, Fakultas Geografi, Universitas Gadjah Mada.

[7] Soemarno,1995, Hidrologi, Aplikasi Metode Statistik Untuk Analisa Data, Nova, Bandung.

[8] Sri Harto BR, 2000, Hidrologi, Teori, Masalah, Penyelesaian, Nafiri, Yogyakarta.

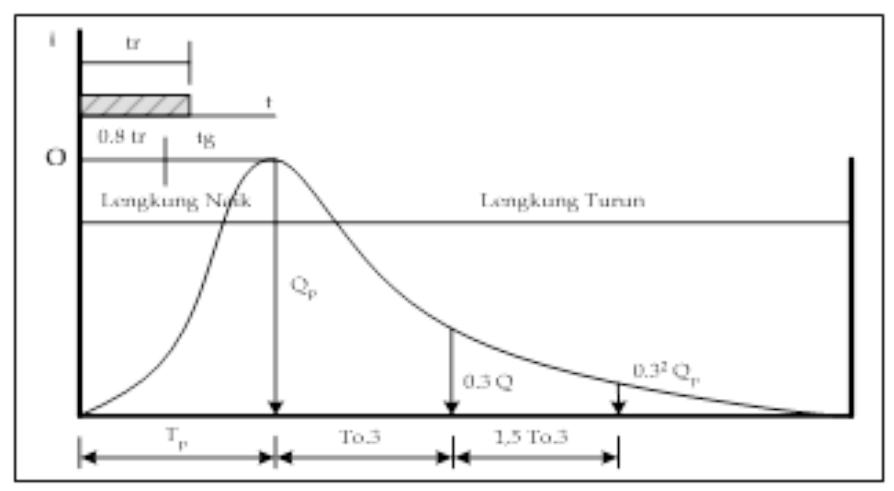

Gambar 1. Sketsa HSS Nakayasu
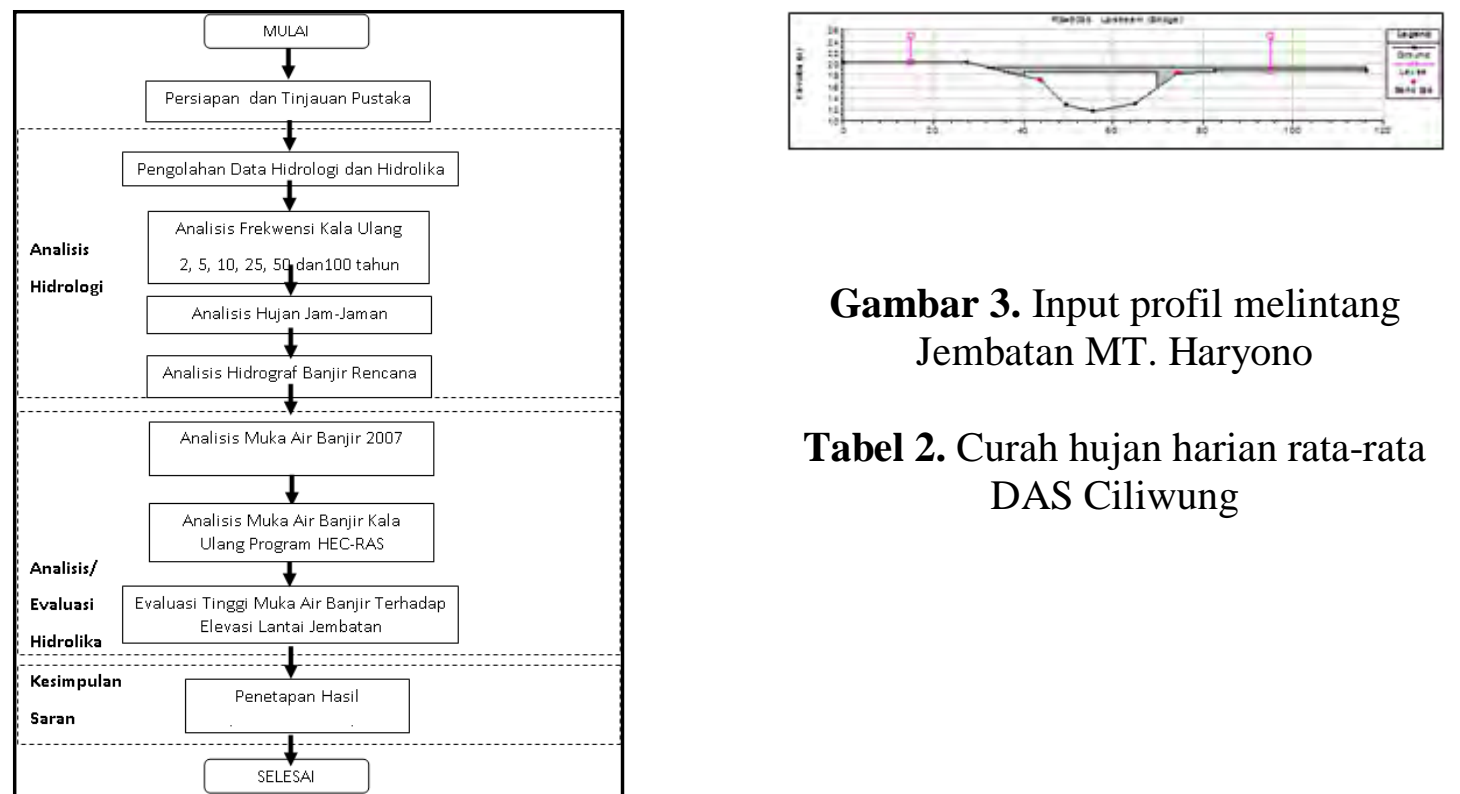

Gambar 3. Input profil melintang Jembatan MT. Haryono

Tabel 2. Curah hujan harian rata-rata DAS Ciliwung

Gambar 2. Diagram alir penelitian

Tabel 1. Curah hujan rata-rata eksisting Februari 2007

\begin{tabular}{|c|c|c|c|c|c|}
\hline Sobur & Stanias & $\operatorname{les}(k=2)$ & Babet Lan & 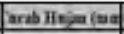 & CH Sesant (ne) \\
\hline 1 & $H A=P K$ & 2169 & 0.069 & 249 & 17.226 \\
\hline 2 & Depx́ & $92 x$ & 0.286 & 132 & 37.207 \\
\hline 3 & Xaniding & 2962 & 0.648 & 172 & 111.128 \\
\hline & Fonl & 52357 & 19 & & 166360 \\
\hline
\end{tabular}




\begin{tabular}{|c|c|c|}
\hline No & Tahm & $\begin{array}{c}\text { Ratarsata } \\
\text { Thiessen (mm) }\end{array}$ \\
\hline 1 & 1999 & 118.0 \\
\hline 2 & 2001 & 125.0 \\
\hline 3 & 2002 & 125.0 \\
\hline 4 & 2003 & 43.2 \\
\hline 5 & 2003 & 61.8 \\
\hline 6 & 2003 & 49.1 \\
\hline 7 & 2004 & 49.4 \\
\hline 8 & 2004 & 63.2 \\
\hline 9 & 2005 & 56.7 \\
\hline 10 & 2006 & 73.3 \\
\hline 11 & 2006 & 78.2 \\
\hline 12 & 2007 & 124.1 \\
\hline 13 & 2007 & 73.0 \\
\hline 14 & 2008 & 124.1 \\
\hline 15 & 2008 & 52.1 \\
\hline 16 & 2008 & 61.3 \\
\hline 17 & 2008 & 64.2 \\
\hline 15 & 2005 & 92.6 \\
\hline 19 & 2009 & 82.4 \\
\hline 20 & 2009 & 82.4 \\
\hline 21 & 2010 & 65.8 \\
\hline 22 & 2010 & 65.8 \\
\hline 23 & 2010 & 68.1 \\
\hline 24 & 2011 & 54.6 \\
\hline 25 & 2011 & 78.8 \\
\hline 15 & & \\
\hline
\end{tabular}

Tabel 3. Hasil perhitungan hujan rancangan sesuai kala ulang hujan

\begin{tabular}{|c|c|c|}
\hline No & $\begin{array}{c}\text { Kala-Ulang (Tr) } \\
\text { Tahun }\end{array}$ & $\begin{array}{c}\text { Hujan Harian Maksimum } \\
\text { Tahunan (mm) }\end{array}$ \\
\hline 2 & 2 & 71.7 \\
\hline 3 & 5 & 95.1 \\
\hline 4 & 10 & 111.9 \\
\hline 5 & 20 & 128.9 \\
\hline 6 & 50 & 152.5 \\
\hline 7 & 100 & 171.5 \\
\hline
\end{tabular}

Tabel 4. Distribusi hujan jam-jaman eksisting bulan Februari 2007

\begin{tabular}{|c|c|c|c|c|c|}
\hline \multirow{2}{*}{$\begin{array}{l}\text { Hipn } \\
\text { Sesantid }\end{array}$} & \multirow{2}{*}{$\begin{array}{c}\text { Conhllijen } \\
\text { (R.s) }\end{array}$} & \multicolumn{4}{|c|}{ Dsurtesi Huga Iam - gman } \\
\hline & & $T 1=63 \%$ & $\mathrm{~T} 2=17 \%$ & $\mathrm{~T} 3=10 \%$ & $\mathrm{~T} t=10 \%$ \\
\hline 32207 & 166.36 & DASBI & 2828 & 16.69 & 16.64 \\
\hline
\end{tabular}

Tabel 5. Distribusi rencana hujan Jam jaman sesuai kala ulang $\left(T_{r}\right)$

\begin{tabular}{|c|c|c|c|c|c|}
\hline \multirow{2}{*}{$\begin{array}{c}\mathrm{Kab} \text { than } \\
(\mathrm{Tt})\end{array}$} & \multirow{2}{*}{ 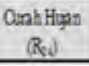 } & \multicolumn{4}{|c|}{ DstbsiHandiem-iman } \\
\hline & & $\mathrm{T} 1=63 \%$ & $\mathrm{~T} 2=17 \%$ & $\mathrm{~T} 3=10 \%$ & $\mathrm{~T} 4=10 \%$ \\
\hline$?$ & 717 & $\$ 18$ & D19 & 7.17 & 717 \\
\hline 5 & 9.14 & $\$ 94$ & 1617 & 9.51 & 951 \\
\hline 10 & 111.8 & 70.9 & 1902 & 11.19 & 118 \\
\hline 30 & 18.99 & 812 & 2192 & 12.99 & 129 \\
\hline$\$ 0$ & 155 & $\$ 09$ & $\$ 93$ & $\$ 15$ & 153 \\
\hline 100 & 171.5 & 10805 & 2016 & 1715 & 1715 \\
\hline
\end{tabular}

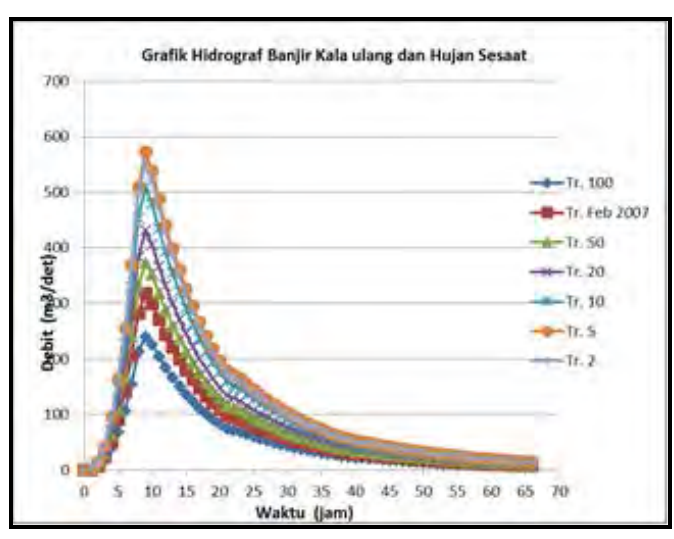

Gambar 4. Grafik hidrograf banjir Ciliwung sesuai kala ulang $\left(\mathrm{T}_{\mathrm{r}}\right)$

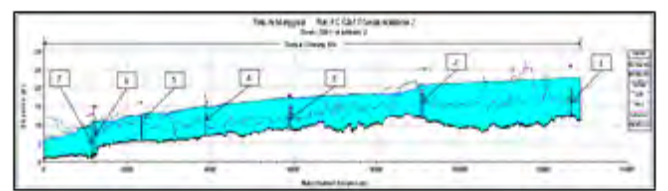

Gambar 5. Grafik MAB sepanjang alur sungai pengamatan

Tabel 6. Hidrograf banjir DAS

Ciliwung gabung sesuai kala ulang $\left(\mathrm{T}_{\mathrm{r}}\right)$

\begin{tabular}{|c|c|c|c|c|c|c|c|}
\hline \multirow{3}{*}{$\begin{array}{l}\text { Whin } \\
\text { (Fin) }\end{array}$} & \multicolumn{7}{|c|}{ Bidogd fat $Q$ (as $/ d k)$} \\
\hline & \multicolumn{6}{|c|}{ Kas theg (Tinr) } & \multirow{2}{*}{$\begin{array}{l}\text { Hexpe } \\
\text { Feb } 200^{\circ}\end{array}$} \\
\hline & $\pi \cdot 2$ & b5 & If 10 & If 20 & It 30 & Tt: 100 & \\
\hline 8 & 600 & $0 x$ & 000 & $0 x$ & 000 & 000 & 080 \\
\hline 1 & 051 & 121 & 143 & 154 & 194 & 215 & $2 \mathrm{~L}$ \\
\hline 2 & 612 & 82 & 955 & 110 & BO? & 1464 & 420 \\
\hline 3 & 183 & 2618 & 54 & $52 \pi$ & $3 \pi$ & 456 & 55 \\
\hline 4 & 402 & 339 & 802 & 29 & 592 & 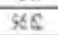 & 586 \\
\hline 5 & 50 & 915 & 10\% & 124 & 1458 & 16366 & two \\
\hline 8 & 1268 & 1481 & $4 \%$ & $15 \div 8$ & 221 & 3367 & 258 \\
\hline 7 & $154 \pi$ & .0530 & $2+126$ & 28212 & 9915 & 3013 & $358 \mathrm{~B}$ \\
\hline 8 & 132 & 3885 & 325 & 3632 & 45399 & W995 & 4944 \\
\hline 9 & 997 & 3599 & 5401 & 43094 & 509 & 53931 & 5558 \\
\hline 10 & 257 & $\$ \$ 4$ & 35215 & 4576 & $4 \mathrm{SCC}$ & 3991 & 523,5 \\
\hline II & $2+15$ & 2783 & 5185 & 3503 & 4342 & 5928 & 4739 \\
\hline 11 & 1546 & 2458 & 3516 & 33199 & 3327 & $416^{\circ}$ & $48 x$ \\
\hline 15 & 16704 & $2 \pi 19$ & 305 & 3030 & $535 ?$ & 3951 & 3873 \\
\hline 14 & 1510 & $2 x 4$ & 335 & 246 & $521 \%$ & 3013 & $3303 \%$ \\
\hline 15 & 1966 & $15 \mathrm{t} 30$ & $25 \%$ & 260 & 38 & $368^{\circ}$ & $316 x$ \\
\hline 16 & 135 & 1506 & $19: 5$ & 223 & $262 \%$ & 85.97 & 256 \\
\hline 17 & 1118 & 1834 & $17+4$ & $\$ 463$ & 378 & 294 & 2599 \\
\hline 18 & 1115 & 13415 & 1578 & $18: 4$ & 21513 & 5191 & 2343 \\
\hline 19 & 9149 & 1213 & 1427 & 15448 & 1945 & 2882 & 21215 \\
\hline 20 & 827 & 1578 & 1913 & 1587 & 17604 & 15753 & $191 \$$ \\
\hline 21 & 786 & 993 & 11688 & 13458 & 1597 & 1903 & 17358 \\
\hline 22 & 7191 & 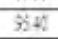 & 1122 & 1938 & $152 \%$ & 17199 & $16 \%$ \\
\hline 23 & 698 & S154 & 1073 & 12420 & 1655 & 16523 & 16019 \\
\hline 24 & $A \Delta$ & $35=2$ & 100 & 11516 & 134 & 1434 & 1698 \\
\hline 2 & 606 & 817 & 48 & $1 \times 65$ & $12 \pi s$ & 1454 & 14513 \\
\hline 26 & 565 & 298 & 819 & 1962 & 1202 & 13319 & 13166 \\
\hline$?$ & 598 & 2013 & 94 & sho & 1124 & 1864 & 1223 \\
\hline 29 & 496 & $85 ; 9$ & 715 & 185 & 1017 & 11826 & 1146 \\
\hline 9 & 465 & 5135 & 716 & 934 & 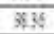 & $110 \leqslant !$ & 1073 \\
\hline 30 & 435 & 5738 & 548 & $77 \%$ & 500 & $109+5$ & 100,0 \\
\hline 5I & 4046 & $536^{\circ}$ & 511 & 223 & $86 \mathrm{CH}$ & $96 \%$ & $5 \$ 1$ \\
\hline 32 & $3 t: 4$ & 5030 & 504 & 65 & 304 & 9050 & 54 \\
\hline
\end{tabular}




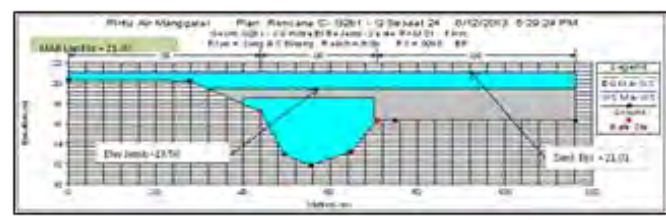

Gambar 6. Profil MAB pada profil melintang Jembatan MT.Haryono

Tabel 7. Elevasi MAB hasil simulasi kalibrasi model S. Ciliwung

\begin{tabular}{|c|c|c|c|c|c|}
\hline \multicolumn{2}{|c|}{ Bangunan Jembatann } & \multirow[b]{2}{*}{ River Station (RS) } & \multicolumn{3}{|c|}{ Elevasi Struktrur/ MAB } \\
\hline & Eksisting & & $\begin{array}{l}\text { Lantai } \\
\text { Jen Tanzedul }\end{array}$ & MAB 2007 & Run HEC- \\
\hline & Kalikbata & $12655 \mathrm{BRU}$ & 20.00 & 22.25 & \\
\hline 2. & MT Haryono & $9095 \mathrm{BR} U$ & 19.90 & 21.00 & 21.01 \\
\hline 3. & Casablangka & 5911 BR U & 15.00 & 1696 & 16.92 \\
\hline 4. & Bukitdan & 35571 & 13.75 & 15.25 & 15.21 \\
\hline 5. & Slamet Riyadi & $2350 \mathrm{BRU}$ & 13.25 & 13.05 & 12.98 \\
\hline 6. & Mangarara & $1224 \mathrm{~B}$ & 11.50 & 10.90 & 10.89 \\
\hline & PA. Manzzarai & 1098 BKB Inl Str & 9.99 & 10.90 & 10.85 \\
\hline
\end{tabular}

Tabel 8. MAB hasil pengamatan eksisting dan simulasi kalibrasi model

\begin{tabular}{|c|c|c|c|c|c|c|c|c|}
\hline \multirow[b]{2}{*}{ so } & \multicolumn{2}{|c|}{ 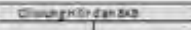 } & \multirow[b]{2}{*}{ 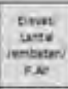 } & \multirow{2}{*}{ 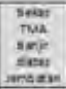 } & \multirow{2}{*}{ 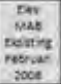 } & \multirow{2}{*}{ 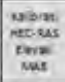 } & \multirow[b]{2}{*}{ stin } & \multirow[b]{2}{*}{ wen } \\
\hline & 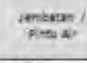 & $\operatorname{con}_{182}$ & & & & & & \\
\hline & & & & 279 & & & & \\
\hline & & & & & & & & \\
\hline & & & & & & & & \\
\hline & & & & & & & & \&s \\
\hline & & & & & & & 0 & \\
\hline
\end{tabular}

Tabel 9. Selisih MAB kala ulang elevasi lantai Jembatan MT.Haryono

\begin{tabular}{|c|c|c|c|c|}
\hline No & kata glang (I) & 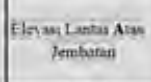 & $\begin{array}{l}\text { EV MAAB Simulad } \\
\text { BEC-RAS Seriai } \\
\text { Kala Uiling }\end{array}$ & 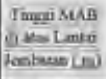 \\
\hline 1 & $\frac{1}{2}$ & 1030 & 1855 & -0.95 \\
\hline 2 & 5 & 19,50 & 180 & $-0,05$ \\
\hline 3 & in & 1996 & 50.02 & -0.97 \\
\hline$A$ & $m$ & 19.50 & 30.16 & +0.66 \\
\hline 5 & 50 & 10,50 & 60.81 & -1.11 \\
\hline 6i & 300 & 1990 & 21.10 & -160 \\
\hline 3 & Asuiting 20007 & 1090 & 21.02 & -1.52 \\
\hline
\end{tabular}

Tabel 10. Elevasi lantai bawah jembatan MT. Haryono yang direkomendasikan

\begin{tabular}{|c|c|c|c|c|c|c|}
\hline No & $\begin{array}{c}\text { Kala Ulang } \\
\text { (Tr) }\end{array}$ & $\begin{array}{c}\text { Elevasi } \\
\text { Lantai } \\
\text { Alas } \\
\text { Jembatan }\end{array}$ & $\begin{array}{c}\text { Elerasi } \\
\text { Bawah } \\
\text { Lumai } \\
\text { Jembontan }\end{array}$ & $\begin{array}{c}\text { Elv MAB } \\
\text { Kala Ulang } \\
\text { Simulasi } \\
\text { HEC-RAS }\end{array}$ & $\begin{array}{c}\text { Tinggi Air } \\
\text { Diatas } \\
\text { Lantai } \\
\text { Jembatan }\end{array}$ & $\begin{array}{c}\text { Rekomendasi } \\
\text { Elevasi Lantai } \\
\text { Bawah } \\
\text { Jembantan }\end{array}$ \\
\hline 1 & 2 & 19.50 & 18.50 & 18.55 & -0.95 & +19.50 \\
\hline 2 & 5 & 19.50 & 18.50 & 19.59 & +0.09 & +20.50 \\
\hline 3 & 10 & 19.50 & 18.50 & 20.07 & +0.57 & +21.00 \\
\hline 4 & 20 & 19.50 & 18.50 & 20.16 & +0.66 & +20.10 \\
\hline 5 & 50 & 19.50 & 18.50 & 20.81 & +1.31 & +21.80 \\
\hline 6 & 100 & 19.50 & 18.50 & 21.10 & +1.60 & +22.10 \\
\hline 7 & Feb 2007 & 19.50 & 18.50 & 21.02 & +1.52 & +22.00 \\
\hline
\end{tabular}

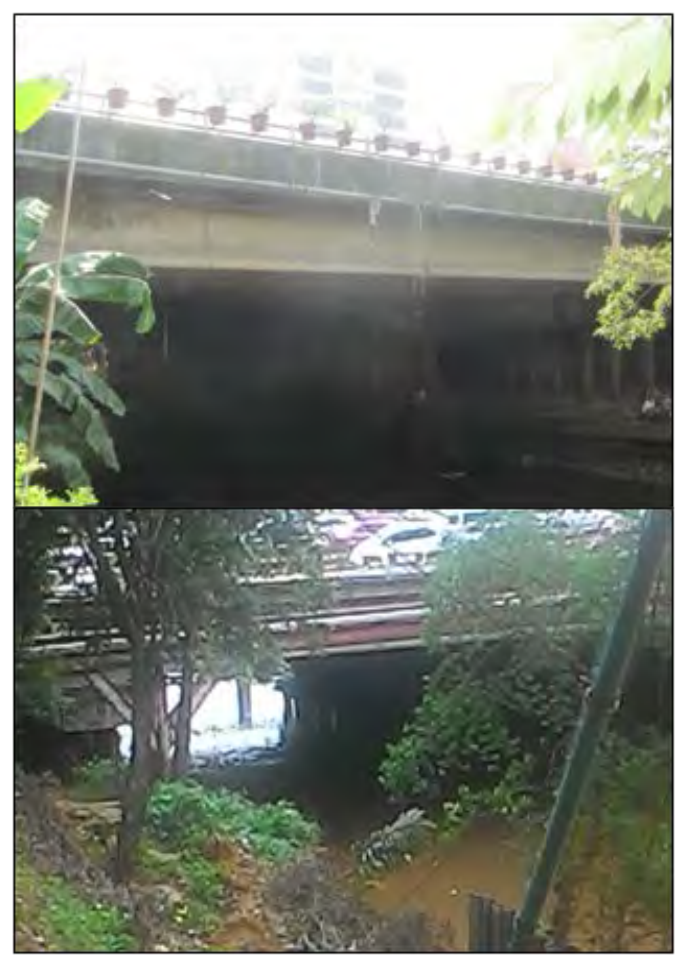

Gambar 7. Foto Jembatan MT. Haryono kondisi aliran normal dan bekas batas MAB pada lantai jembatan 
Mursid MA, Deny Yatmadi, Perkiraan Tinggi Standar... 